\title{
IMPLEMENTASI TOTAL BRANDING DALAM PERSPEKTIF SEMIOTIKA PEMASARAN
}

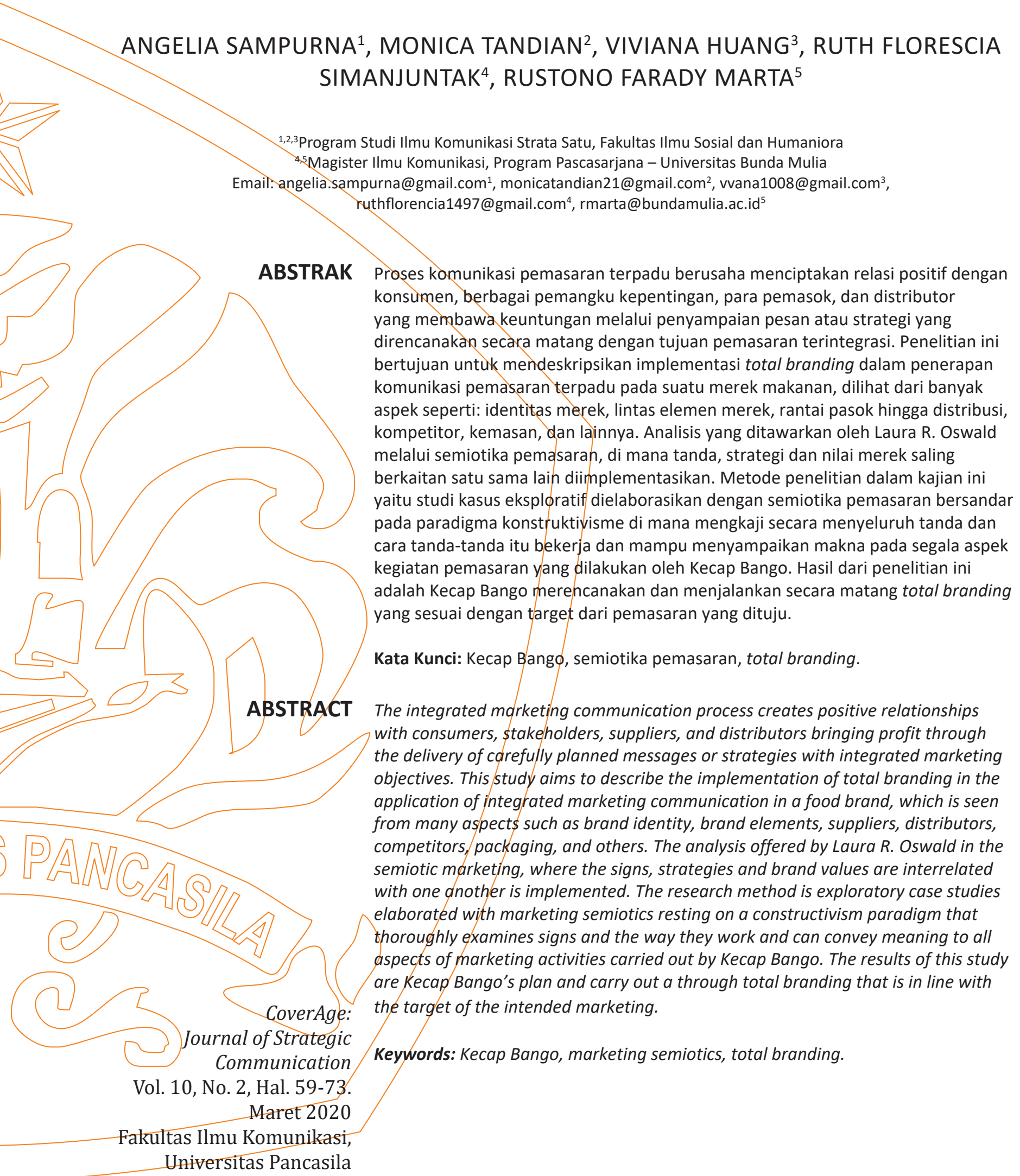

Diterima 3 Februari 2020

Disetujui 2 Maret 2020 
ANGELIA SAMPURNA, MONICA TANDIAN, VIVIANA HUANG, RUTH FLORESCIA SIMANJUNTAK, RUSTONO FARADY MARTA

\section{PENDAHULUAN}

Komunikasi pemasaran salah satu hal yang penting bagi perusahaan untuk membantu kegiatan pemasaran. Pemasaran sebagai upaya memperkenalkan perusahaan kepada masyarakat luas sehingga membutuhkan strategi pemasaran yang tepat dan tepat sasaran. Pemasaran dengan komunikasi merupakan hubungan yang erat (Mulyadi \& Mulia, 2020).

Komunikasi sebagai proses pengoperan lambang-lambang yang diartikan sama antara individu kepada individu, individu kepada kelompok, kelompok kepada kelompok, dan kelompok kepada massa. Komunikasi dalam kegiatan pemasaran bersifat kompleks, artinya tidak sesederhana seperti ketika kita berbincang-bincang dengan rekan sekantor, atau dengan keluarga dirumah (Lestari, 2015).

Komunikasi pemasaran sebagai salah satu bagian dari strategi pemasaran untuk mendapatkan pelanggan, baik yang baru maupun yang lama agar pelanggan tertarik dan membeli produk tersebut. Strategi pemasaran menggambarkan ekspektasi perusahaan akan dampak dari kegiatan pemasaran terhadap permintaan produk di pasaran tertentu.

Bentuk komunikasi ini mendorong penyampaian pesan yang dilakukan melalui sejumlah strategi komunikasi yang canggih, setelah melewati proses perencanaan yang matang. Komunikasi dipengaruhi oleh berbagai bentuk media yang digunakan, daya tarik pesan, frekuensi penyajian dan dalam hal penyampaian pesanpesan komunikasi yang dihadapkan pada berbagai persoalan, seperti: perbedaan persepsi, perbedaan budaya dan keterbatasan media yang digunakan.

Definisi IMC dalam pemaparan (UIfa \& Marta, 2016) adalah suatu konsep perencanaan komunikasi pemasaran yang memberikan nilai tambah terhadap suatu perencanaan yang mendalam dengan cara melakukan evaluasi terhadap beberapa peran strategis yang ada dalam macam ilmu komunikasi kemudian mengombinasikannya untuk menghasilkan konsistensi, keakuratan dan efek komunikasi secara maksimal melalui integrasi dari pesan-pesan yang terpisah.

Menurut Bruhn (2017) dalam (Sari \& Semiarty, 2019) IMC merupakan konsep komunikasi yang menjanjikan karena konsep ini lebih dari sekedar integrasi, koordinasi dan penyatuan instrumen komunikasi IMC yang membahas tentang posisi strategis, masalah manajerial, organisasi dan personal serta bagaimana hubungan satu dengan lainnya. IMC juga berpotensi besar dalam memengaruhi kinerja bisnis untuk memberikan keunggulan kompetitif pada perusahaan agar meningkatkan ekuitas merek kemudian memastikan efektivitas dan konsistensi komunikasi dengan memfasilitasi pencapaian komunikasi dan tujuan pemasaran.

Ada beberapa faktor yang memengaruhi perkembangan konsep dari IMC, di mana di dalamnya dipengaruhi oleh segala aspek termasuk dari merek itu sendiri. Brand atau merek adalah sebuah label unik berupa desain, simbol, kata, atau kombinasi dari semua item tersebut yang melekat sebagai identitas pada sebuah produk atau jasa dan menjadi ciri atau identitas khusus yang membedakan dengan produk atau jasa dari pesaing lainnya. Merek yang mewakili produk atau jasa dari sebuah perusahaan perlu diperkenalkan kepada publik agar merek tersebut dikenal luas oleh masyarakat, oleh sebab itu dilakukanlah kegatan pemasaran. Kegiatan pemasaran sendiri oleh AMA (American Marketing Association) dalam buku Advertising and Promotion: An Integrated Marketing Communication Perspective dalam (Belch, 2009) didefinisikan sebagai berikut;

\section{"Marketing is the activity, set of institutions, and process for creating, communicating, delivering, and exchanging offerings that have value for customers, clients, partners, and society at large."}

Integrated Marketing Communication berawal pada tahun 1980-an di mana banyak perusahaan mulai mencari perspektif yang lebih luas untuk melakukan komunikasi pemasaran dan kebutuhan akan strategi yang lebih terintegrasi dari alat promosi yang selama ini digunakan. Industri periklanan menyadari bahwa Integrated Marketing Communication bukan hanya sebuah trend, melainkan merupakan sebuah kegiatan periklanan, orchestra, dan komunikasi yang tulus yang digunakan sebagai definisi dari konsep integrasi. Definisi dari Integrated Marketing Communication menurut American Association of Advertising Agencies (the "4As") adalah:

"A Concept of marketing communications planning that recognizes the added value of a comprehensive plan that evaluates the strategic roles of a variety communication disciplines for example, general advertising, direct response, sales promotion, and public 
relations and combines there disciplines to provide clarity, consistency, and maximum communication impact."

Definisi dari 4A's berfokus pada proses dari penggunaan semua bentuk alat promosi untuk mencapai dampak komunikasi yang maksimal. Proses dari Integrated Marketing Communications membutuhkan sebuah "gambaran besar" untuk merencanakan pemasaran dan program promosi serta mengkoordinasi berbagai macam fungsi komunikasi (Lubis, 2008). Hal tersebut memerlukan perusahaan mengembangkan strategi komunikasi pemasaran total yang akan mengindikasikan semua kegiatan pemasaran perusahaan, tidak hanya kegiatan promosi, tetapi juga komunikasi dengan konsumen.

Sejak tahun 300 SM, bangsa Romawi sudah menggunakan kecap sebagai penambah kelezatan makanan. Proses pembuatannya terus berkembang hingga pada tahun 1690, bangsa Tiongkok menggunakan saus asin dan diberi nama ke'tsiap. Pembuatan kecap itu yang semakin lama semakin berkembang dan mulai banyak menggunakan kacang kedelai.

Kecap manis banyak digunakan dalam berbagai masakan di Indonesia sebagai bahan penyedap serta pelengkap masakan maupun ditambahkan pada makanan apabila akan disantap. Keamanan dan kualitas dari produk kecap merupakan hal yang penting untuk menjamin keselamatan dan kepuasan konsumen. Oleh sebab itu, produsen dari kecap manis harus benar-benar menjaga kualitas dari produk kecap melalui proses pengolahan yang baik dan benar dari awal hingga produknya jadi sehingga dapat dihasilkan kecap yang bermutu tinggi (Meutia, 2016).

PT. Unilever divisi Food Seasoning merupakan salah satu perusahaan di bidang pangan yang memproduksi kecap manis. Perusahaan ini merupakan salah satu perusahaan terkemuka di Indonesia, yang menghasilkan produk-produk yang sangat inovatif dan kreatif juga beragam. Produk yang dihasilkan tidak hanya makanan, tetapi juga minuman, pembersih, hingga perawatan tubuh. Produk tersebut telah diterima oleh masyarakat Indonesia dengan baik, baik melalui kualitas dan mutu dari produk, pelayanan, kegiatan pemasaran, promosi, hingga komunikasi dengan konsumen.

Paul Southgate dalam jurnalnya, menyebutkan jika total branding merupakan pendekatan baru untuk pengepakan desain, mencakup perkenalan terhadap pendekatan untuk membangun merek, beberapa masalah spesifik dan contoh tentang cara kerja dan keuntungan dari penjualan (Southgate, 1995).

Dasar dari teori ini sangatlah mudah. Total branding menggunakan seluruh aspek dengan sengaja dan asecara aktif mengomunikasikan nilai-nilai merek tersebut, baik melalui logo yang mudah diingat dan mencoba menggunakan setiap aspek dari kemasan merek untuk memberikannya identitas yang mudah diingat. Disamping itu, melibatkan indera sentuhan konsumen (baik itu melalui bentuk, struktur dan bahan) serta indera penglihatan.

Total branding merupakan gambaran tentang menggunakan desain untuk mengomunikasikan manfaat dan kepribadian merek, bukan hanya fitur produk. Singkatnya, tentang menjadikan paket desain sebagai kontributor kerja keras untuk nilai-nilai merek di setiap level. Selanjutnya, total branding adalah tentang bagaimana perusahan menjaga baik citra yang ingin dibentuk dari hulu ke hilir, dimulai dari kontributor, supplier, distributor, kompetitor maupun pelanggan.

\section{TINJAUAN PUSTAKA}

Dalam penjelasan Farady \& Septyana (2015) semiotika berasal dari kata Yunani semeion, yang berarti tanda. Semiotika atau semiology menurut Fiske (2004) adalah suatu studi mengenai tanda dan cara tanda-tanda itu bekerja.

Dalam Introducing Social Semiotics karya Van Leeuwen dalam (Marta, 2015) istilah wacana sering digunakan untuk menunjukkan suatu bagian secara luas dari tuturan maupun tulisan yang berhubungan dengan teks yang ada dalam sebuah gambar atau logo.

Menurut Saussure, semiologi didasarkan pada anggapan bahwa perbuatan dan tingkah laku manusia akan membawa sebuah makna, serta makna suatu tanda bukanlah makna bawaan melainkan dihasilkan lewat sistem tanda yang dipakai dalam kelompok orang tertentu. Pierce berpendapat bahwa penalaran manusia senantiasa dilakukan lewat tanda, artinya manusia hanya mampu bernalar melalui tanda (Sunardi, 2004).

Semiotika bukanlah ilmu yang mempunyai sifat kepastian, ketunggalan dan objektivitas melainkan dibangun oleh pengetahuan yang lebih terbuka bagi aneka intepretasi, diketahui bahwa logika intepretasi bukanlah logika matematis, yang 
ANGELIA SAMPURNA, MONICA TANDIAN, VIVIANA HUANG, RUTH FLORESCIA SIMANJUNTAK, RUSTONO FARADY MARTA

hanya mengenal kategori benar atau salah. Logika semiotik adalah logika di mana interpretasi tidak diukur berdasarkan salah atau benarnya, melainkan derajat kelogisannya (Tinarbuko, 2008).

Pemasaran sebagai ilmu yang mempelajari pertukaran nilai atau value exchange, dengan terjadinya perubahan lingkungan usaha telah terjadi penyesuaian-penyesuaian paradigma (Haryono, 2015). Oleh karena itu, peneliti menyertakan konsep-konsep yang berkaitan dengan penelitian seperti teori hingga konteks pada pemasaran yang ada untuk menjelaskan argumen serta intepretasinya. Teori yang peneliti sertakan dianggap mampu untuk menjelaskan setiap implementasi yang ada pada Total branding yang ada pada Kecap Bango.

\section{Semiotika Pemasaran}

Laura R. Oswald adalah seorang antropolog Iulusan New York University yang pertama kali menemukan dan memperkenalkan teori Marketing Semiotics atau Semiotika Pemasaran. Dalam teorinya, Oswald berusaha menjelaskan penerapan semiotika, ilmu yang mempelajari tentang tanda dan proses bekerjanya. Tanda tersebut dalam pemasaran yang terkait dengan strategi merek (brand) dan konsumen. Dalam beberapa buku yang menjelaskan hubungan marketing dan semiotics, banyak yang fokus terhadap penjelasan makna pembuatan iklan. Iklan dianggap merupakan mekanisme yang digunakan pemasar untuk menyampaikan makna atau persepsi dari konsumen terhadap suatu merek (Oswald, 2012).

Teori marketing semiotics Oswald memiliki tiga komponen penting yaitu tanda, strategi, dan nilai citra merek (Oswald, 2012). Banyak pengamat yang berpendapat bahwa citra merek suatu organisasi atau perusahaan dinilai dari produk, logo, dan iklan. Di sisi lain, sebenarnya citra merek terbentuk melalui hubungan kompleks antara komersial, budaya, dan tekanan sosial. Kekuatan merek bukan hanya dinilai dari citra merek, atau esensi merek suatu organisasi atau perusahaan, tetap juga dinilai dari pemaknaan pada pola pikir konsumen.

\section{Public Relations}

Public Relation dalam (Ishak, 2012) dipandang memiliki fungsi yang bermakna sebagai suatu jembatan (bridge) antara perusahaan atau organisasi kepada public. Istilah public relations diperkenalkan oleh Ivy Ledbetter Lee pada tahun
1906. Institude of public relations mendefinisikan public relations sebagai berikut: "public relations adalah keseluruhan upaya yang dilakukan secara terencana dan berkesinambungan dalam rangka menciptakan dan memelihara niat baik (goodwill) dan saing pengertian antara satu perusahaan dengan segenap khalayaknya."

$\mathrm{Hal}$ ini berarti bahwa public relations adalah satu rangkaian kegiatan kampanye atau program terpadu yang berlangsung secara berkesinambungan dan teratur sehingga terdapat pengertian dan pemahaman dari pihak-pihak yang berkepentingan. Tujuan utamanya adalah menciptakan dan memelihara saling pengertian dengan maksud untuk memastikan bahwa organisasi tersebut senantiasa dimengerti oleh pihak lain yang turut berkepentingan. Sebaliknya, organisasi juga harus memahami kelompok atau individu yang terlibat didalamnya (Jefkins, 1997).

\section{Marketing Public Relations}

Marketing Public Relations (MPR) merupakan proses perencanaan dan mengevaluasi programprogram yang merangsang pembelian dan kepuasan konsumen melalui komunikasi mengenai informasi yang dapat dipercaya dan melalui kesan-kesan yang menghubungkan perusahaan dan produknya sesuai dengan kebutuhan, keinginan, perhatian dan kepentingan konsumen ("Konsep Marketing Public Relation (MPR): Definisi dan Peran Marketing Public Relation," 2009).

Program yang dijalankan oleh marketing public relations dalam penjelasan (Rosyadi, 2018) merupakan proses perencanaan, pelaksanaan dan pengevaluasian program berguna untuk kepuasan konsumen melalui komunikasi yang menghubungkan perusahaan dan produknya sesuai dengan kebutuhan, keinginan, perhatian dan kepentingan konsumen.

Peran komunikasi dalam konteks pemasaran dijelaskan dalam (Tarsani, 2016) merupakan pemenuhan dan pemuasan bagi konsumen, sedangkan pemasaran sendiri menjadi sarana suatu perusahaan atau organisasi agar dapat mengetahui kebutuhan manusia yang tak terpenuhi kemudian menjadi peluang usaha agar menciptakan pemenuhan kebutuhan guna dapat mempertahankan hidup serta mendapatkan keuntungan yang di mana semua bergantung pada kemampuan penciptaan keinginan manusia yang selalu berubah atau dinamis. 


\section{Brand Identity}

Identitas merek (brand identity) adalah seperangkat asosiasi merek yang unik yang diciptakan oleh para penyusun strategi merek. Asosiasi-asosiasi ini mencerminkan kedudukan suatu merek dan merupakan suatu janji kepada pelanggan dari anggota organisasi. Identitas merek akan membantu kemantapan hubungan diantara merek dan pelangan melalui proposisi nilai yang melibatkan manfaat fungsional, manfaat emosional atau ekspresi diri (Kotler \& Keller, 2007).

Brand Identity merupakan asosiasi merek yang unuk yang menunjukkan janji kepada konsumen. Agar menjadi efektif, identitas merek perlu beresonansi dengan konsumen, membedakan merek dari pesaing, dan mewakili apa organisasi dapat dan akan lakukan dari waktu ke waktu (Aaker, 2008).

Elemen brand adalah upaya visual bahkan kadangkala fisik yang bertindak mengidentifikasi dan mendeferensiasi suatu produk atau jasa perusahaan. Elemen brand formal seperti nama, jenis logo, dan slogan Bersatu membentuk identitas visual suatu brand atau perusahaan (Kotler \& Philip \& Pfoetsch W, 2006).

Beberapa elemen brand identity dalam pemaparan (Kotler \& Philip \& Pfoetsch W, 2006) adalah sebagai berikut; (1) Nama merek adalah yang pertama dan mungkin ekspresi terbesar atau wajah dari suatu produk. Nama yang dipilih dengan baik suatu perusahaan, produk, atau jasa dapat menjadi aset berharga, seperti halnya brand itu sendiri. Nama brand akan digunakan dalam segala bentuk komunikasi antar perusahaan dengan konsumen prospektifnya. (2) Logo adalah tampilan grafis dari nama merek atau perusahaan. Kekuatan simbol tidak boleh dianggap remeh "karena manusia cenderung menjadi lebih mudah meneruma citra dan simbol dibanding yang lainnya, logo yang kuat dapat memberi kohesi dan membangun kesadaran identitas brand, memudahkan pengenalan dan ingatan kembali". (3) Slogan brand adalah kalimat yang mudah dikenal dan diingat yang seringkali menyertai nama brand dalam program komunikasi pemasaran. Tujuan utama slogan adalah mendukung citra merek yang diproyeksikan oleh nama dan logo merek. (4) Kisah dapat menjadi lebih dan lebih penting dalam kehidupan perusahaan. Sebagai suatu konsep, kisah bahkan dapat memenangkan tempat berpijak yang penting dalam perdebatan tentang cara brand masa depan akan dibentuk.

\section{Brand Image}

Brand Image (citra merek) menurut Ship (2007) dalam pemparan (Fensi \& Christian, 2018) adalah suatu kumpulan asosiasi merek yang didasarkan berbagai ketertarikan yang dikembangkan oleh konsumen pada setiap waktu, brand seperti manusia yang di mana terdapat suatu gagasan yang mempunyai masing-masing personality atau kepribadian.

Brand Image dari suatu produk yang baik akan mendorong para calon pembeli untuk membeli produk tersebut daripada membeli produk yang sama dengan merek lain. Karena itu penting bagi perusahaan untuk memperhatikan perilaku pembelian mereka guna menentukan langkah yang tepat untuk mengantisipasinya (Venessa \& Arifin, 2017).

Menurut pendapat Kotler dan Keller dalam (Tumpal \& Hasugian, 2015) pengukuran citra merek adalah subjektif, artinya tidak ada ketentuan baku untuk pengukuran citra merek (brand image). Bahwa pengukuran citra merek dapat dilakukan berdasarkan pada aspek sebuah merek yaitu Stengthness, Uniqueness, dan Favorable (Tumpal \& Hasugian, 2015). (1) Strengthness, di mana kekuatan dalam hal ini adalah keunggulankeunggulan yang dimiliki oleh merek yang bersifat fisik dan tidak ditemukan pada merek lainnya. Keunggulan merek ini mengacu pada atributatribut fisik atas merek tersebut sehingga biasa dianggaap sebagai sebuah kelebihan dibandingkan dengan merek lain, yang termasuk pada kelompok strength ini antara lain: fisik produk, keberfungsian semua fasilitas produk, harga produk, maupun penampilan fasilitas pendukung dari produk tersebut. (2) Uniqueness, Keunikan adalah kemampuan untuk membedakan sebuah merek di antara merek-merek lainnya. Kesan ini muncul dari atribut produk, menjadi kesan unik berarti terdapat diferensiasi antara produk satu dengan produk lainnya. Termasuk dalam kelompok unik ini antara lain: variasi layanan yang biasa diberikan sebuah produk, variasi layanan yang biasa diberikan sebuah produk, variasi harga dari produk-produk yang bersangkutan maupun diferensiasi dari penampilan fisik sebuah produk. (3) Favorable (Kesukaan) Kesukaan mengarah pada kemampuan merek tersebut agar mudah diingat oleh konsumen, yang termasuk dalam kelompok favorable ini antara lain: kemudahan merek tersebut diucapkan, kemampuan merek untuk tetap diingat oleh pelanggan, maupun kesesuaian antara kesan merek 
di benak pelanggan dengan citra yang diinginkan perusahan atas merek yang bersangkutan.

\section{Brand Trust}

Kepercayaan merek adalah perasaan aman yang dimiliki konsumen akibat interaksinya dengan sebuah merek, yang berdasarkan persepsi bahwa merek tersebut dapat diandalkan dan bertanggung jawab atas kepentingan dan keselamatan dari konsumen (Delgado-Ballester \& Munuera-Alemán, 2005).

Menurut Delgado ada dua indikator variabel yang memengaruhi kepercayaan merek (brand trust), yaitu (1) Brand Reliability adalah kehandalan merek yang bersumber pada keyakinan konsumen bahwa produk tersebut mampu memenuhi nilai yang dijanjikan atau dengan kata lain persepsi bahwa merek tersbut mampu memenuhi kebutuhan dan memberikan kepuasan (Delgado-Ballester \& Munuera-Alemán, 2005). Brand reliability merupakan hal yang esensial bagi terciptanya kepercayaan terhadap merek karena kemampuan merek memenuhi nilai yang dijanjikannya akan membuat konsumen menaruh rasa yakin akan mendapatkan apa yang dibutuhkan dalam hal ini kebutuhan untuk keluar dari perasaan terancamnya. (2) Brand Intentions yaitu minat pada merek mencerminkan keyakinan konsumen bahwa merek tersebut mampu mengutamakan kepentingan konsumen ketika masalah dalam konsumsi produk muncul secara tidak terduga. Oleh karena itu, intentionality berkaitan dengan kepercayaan bawa merek akan tertarik pada apa yang dibutuhkan konsumen dan tidak akan mengambil keuntungan dari ketidaktahuan konsumen (Fajrin \& Wibowo, 2018).

\section{Total Branding}

Ungkapan 'total branding' diciptakan oleh penulis dan mitranya Mark Wickens pada tahun 1990 sebagai deskripsi singkat tentang pendekatan desain kemasan yang sedang diperjuangkan perusahaan. Teori dasarnya tampak sederhana, total branding adalah tentang menggunakan seluruh paket dengan sengaja dan aktif untuk mengomunikasikan nilai-nilai merek. Ini adalah tentang melampaui logo yang mudah diingat dan mencoba menggunakan setiap aspek dari kemasan merek untuk memberikannya identitas yang mudah diingat, bagaimana melibatkan indera sentuhan konsumen (melalui bentuk, struktur dan bahan) serta indra penglihatan, bagaimana menggunakan desain untuk mengomunikasikan manfaat dan kepribadian merek, bukan hanya fitur produk. Singkatnya, membuat desain paket menjadi kontributor kerja keras terhadap nilai-nilai merek di setiap level. Selain itu, pada total branding juga dihadapkan dengan beberapa aspek seperti supplier, kompetitor, dan distributor.

\section{Gambar 1.}

\section{Total Branding}

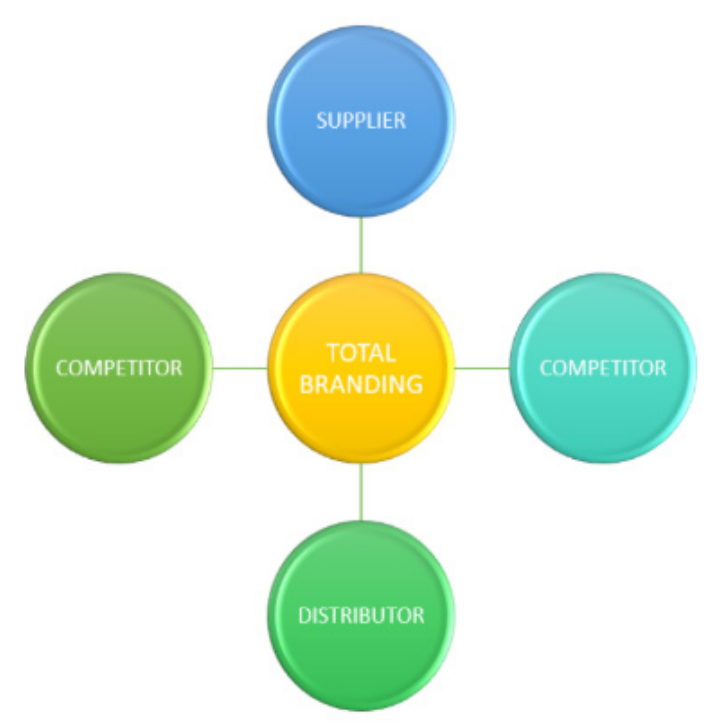

Sumber: Olahan Peneliti

\section{METODE}

Riset ini membahas tentang implementasi total branding dalam komunikasi pemasaran terpadu yang dilakukan oleh Kecap Bango. Penelitian ini dilakukan pada bulan Januari 2020, dengan pendekatan penelitian yang digunakan adalah kualitatif dengan jenis penelitian studi kasus eksploratif dan semiotik dengan paradigma konstruktivisme.

Penelitian ini masuk dalam penelitian kualitatif yang bertujuan untuk menjelaskan sebuah fenomena dengan sejelas-jelasnya dengan berpegang pada pengumpulan data yang sedalamdalamnya (Kriyanto, 2008). Teknik pengumpulan data dalam pendekatan kualitatif dalam (Marta, Fernando, \& Simanjuntak, 2019) yaitu dengan mengumpulkan data secara observasi pada objek penelitian. Kualitatif dijelaskan dalam (Azzahrani, 2018) biasanya dimaksudkan untuk menjelaskan gambaran atau pemahaman mengenai, bagaimana dan mengapa suatu gejala atau realitas komunikasi terjadi. 
Metode penelitian ini menggunakan metodologi penelitian kualitatif dengan jenis penelitian studi kasus digunakan sebagai suatu penjelasan komprehensif yang berkaitan dengan aspek seseorang, suatu kelompok, suatu organisasi, suatu program, atau suatu situasi kemasyarakatan yang diteliti, diupayakan dan ditelaah sedalam mungkin. Studi kasus juga memiliki pengertian berkaitan dengan penelitian yang terperinci tentang seseorang atau suatu unit sosial dalam kurun waktu tertentu (Yin, 2008). Dengan menggunakan pendekatan penelitian kualitatif seperti yang dijelaskan dalam (Johannes, 2017) metode studi kasus yang bersifat eksploratoris menjadi pilihan agar mendapatkan informasi seperti why and how? Atau mengapa dan bagaimana?

\section{HASIL DAN PEMBAHASAN}

Kecap bango pada pemasarannya, menggunakan banyak strategi, baik internal seperti logo, packaging, typografi, tagline, dan lainnya di mana untuk eksternal, ada pemasaran di mana terdapat iklan melalui baliho, banner, media baru, media cetak dan media konvensional. Selain itu, strategi melalui supplier, distributor, dan antara competitor pun sangat diperhatikan.

Kegiatan publisitas bagi strategi pemasaran dalam (Puspitasari, Mahameruaji, \& Indriani, 2017) bertujuan untuk merencanakan dalam rangka mendukung tujuan pemasaran suatu produk atau jasa perusahaan. Pentingnya komunikasi dan bisnis sebagai dua hal yang tidak dapat dipisahkan bagaikan dua mata uang untuk tercapainya kepentingan dan pengertian bersama (Hardhiyanti, 2017).

Terutama dalam hal komunikasi, komunikasi yang persuasif seperti penjelasan dalam (Marta \& William, 2016) menjadi penting karena salah satu dari karakteristik utama komunikasi persuasif ialah komunikasi yang tidak diinginkan. Sehingga hal tersebut menimbulkan suatu perbedaan di benak masyarakat.

Kecap bango didirikan oleh keluarga Tjoa Eng Nio pada tahun 1928 di Tangerang dan merupakan industri rumahan yang kala itu hanya di jajakan di toko kecil di rumahnya. Penjualan Bango ini berkembang pesat dibawah PT. Anugrah Setia lestari yang pendirinya merupakan generasi keempat pengembang kecap Bango hingga ke manca negara dan memiliki omset perbulan sekitar 1 miliar. Setelah akuisisi, nama dari kecap Bango semakin tidak asing di kalangan masyarakat baik dalam maupun luar Jakarta.

Dalam komunikasi pemasaran terpadu terdapat sebuah terminologi yang bernama 'Total branding' di mana Bango melakukan proses branding dari awal hingga pada saat ini dan masih terus berlanjut, dapat dilihat dari beberapa identitas brand yang dimiliki oleh Bango.

Gambar 2.

Gaya Bahasa pada Iklan “Kecap Bango"

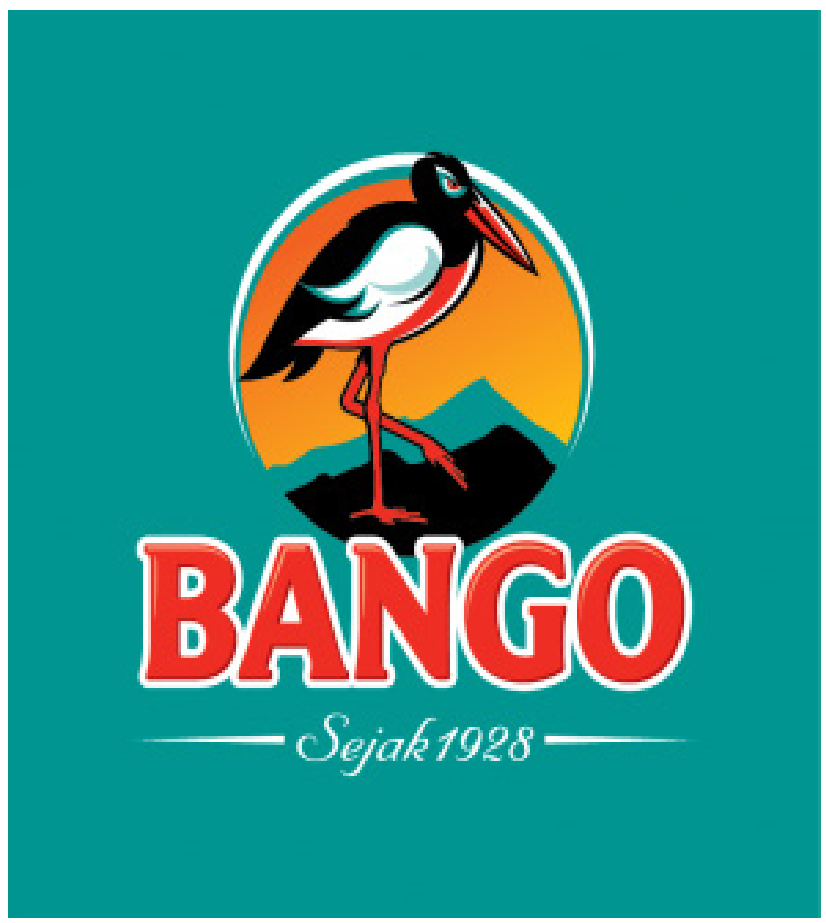

Sumber: Unilever.co.id

\section{Filosofi Merek}

Awalnya, merek kecap ini adalah 'Kecap Bango', tetapi setelah di akuisisi oleh PT. Unilever Indonesia, merek kecap ini dilakukan perubahan baik dari nama, kemasan, dan lainnya. Nama saat ini adalah 'Bango', yang tetap menggunakan filosofi sang pendiri, dengan sebuah visi yakni ingin produk ini dapat terbang tinggi hingga ke manca negara.

Persoalan merek menjadi salah satu upaya yang harus dipantau secara terus menerus oleh setiap perusahaan. Merek-merek yang kuat, teruji, dan bernilai tinggi terbukti tidak hanya sukses mengalahkan hitungan-hitungan rasional, tetapi juga canggih mengolah sisi-sisi emosional konsumen. Merek juga bisa memiliki nilai tinggi karena ada brand building activity yang bukan sekedar berdasarkan komunikasi, tetapi merupakan segala macam usaha lain untuk memperkuat merek tersebut (McAlexander, Schouten, \& Koenig, 2002). 
ANGELIA SAMPURNA, MONICA TANDIAN, VIVIANA HUANG, RUTH FLORESCIA SIMANIUNTAK, RUSTONO FARADY MARTA

Dari komunikasi, merek juga menjanjikan sesuatu, merek juga mensinyalkan sesuatu. Pada filosofi ini, ada kaitannya dengan penamaan, typografi, maupun karakter yang digunakan sebagai merek dari Bango ini.

Filosofi yang ingin disampaikan juga di temukan melalui pemilihan nama merek 'Kecap Bango', di mana merupakan bahasa jawa dari burung bangau, yang diharapkan dapat terbang tinggi dan menjadi produk yang bisa diterima di manca negara. Kecap Bango menggunakan slogan "Benar-benar Kecap". Slogan ini jelas menekankan bahwa produk mereka memiliki kualitas terbaik. Seolah menekankan kepada masyarakat bahwa produk mereka adalah produk asli dan terjamin mutu serta cita rasanya. Jadi, slogan bermakna bahwa hanya kecap Bango-lah yang merupakan kecap terbaik dan terbukti keasliannya. Penggunaan slogan ini tentunya digunakan untuk mempertegas di mana akan memberikan kepuasan tersendiri bagi konsumen karena mempercayai slogan dari produk tersebut.

Bila ditinjau dari segi makna, maka, kita dapatkan bahwa Kecap Bango adalah kecap terbaik yang terjamin keasliannya untuk memberikan cita rasa manis, khususnya, pada makanan. Hal ini didukung pula dari komposisi Kecap Bango dengan pernyataan pada iklan produk tersebut, "Ini Malika, biji kecap terbaik yang dibesarkan dan dihasilkan dari kebun sendiri". Dengan dukungan pernyataan tersebut maka kecap Bango memang benar-benar kecap yang diracik dengan komposisi bahan baku berkualitas dan diproses secara alami. Selain itu, pada gaya bahasa atau tagline yang digunakan ini, dipilih dengan menggunakan pendekatan sosiologis di mana, penekanan 'benar-benar kecap', akan menjadi top on mind ketika para customer mencari kecap.

\section{Logo}

Menurut (Sularko, H., Prawata, V., \& M, 2008) di dalam bukunya yang berjudul "How Do They Think", logo atau bisa disebut dengan Corporate Identity adalah sebuah tanda yang di mana secara langsung tidak menjual, melainkan memberi suatu identitas yang pada akhirnya akan menjadi sebuah alat pemasaran yang signifikan, dan logo nantinya akan mampu juga membantu membedakan suatu produk atau jasa dari pesaingnya. Dari logo Bango sendiri, mencerminkan visi dari pendiri kecap Bango yakni gambar burung bangau yang merupakan karakter dari produk kecap tersebut, di mana terdapat gambar gunung yang menandakan burung bangau yang dapat terbang tinggi.

\section{Brand Name}

Merek atau pelabelan nama dalam penjelasan (Rezki \& Hapsari, 2019) merupakan elemen penting pada suatu produk karena dengan adanya merek tentu akan menjadi suatu nilai tambah pada sebuah produk baik itu berupa barang ataupun jasa.

Merek memegang peranan yang penting, di antaranya yaitu menjembatani harapan konsumen pada saat perusahaan menjanjikan pada konsumen. Merek sebenarnya adalah cerminan dari janji yang diucapkan oleh produsen terhadap konsumen atas kualitas produk yang akan mereka hasilkan. Bahkan, lebih jauh lagi, dapat dikatakan bahwa merek adalah gudang penyimpanan kepercayaan yang semakin penting peranannya seiring dengan meningkatnya jumlah pilihan yang dihadapi masyarakat.

Merek juga merupakan sebuah indikator value yang ditawarkan kepada pelanggan. Merek merupakan intangible asset yang menciptakan value bagi pelanggan dengan memperkuat lotalitas dan kepuasannya. Merek menjadi 'alat ukur', bagi kualitas value yang ditawarkan (Kertajaya, Hermawan, Yuswohadi, Musri, \& Taufik., 2004).

Dalam hal ini, Bango benar-benar memperhatikan nama merek dari produknya. Dimulai dari pemilihan nama, Bango yang berarti Burung Bangau dalam bahasa Jawa. Pemilihan font tulisan pun dibuat besar dan bold, karena untuk menggambarkan kekentalan dan seberapa besar kekuatan yang dimiliki oleh merek Bango itu, di mana dalamnya, ada tujuan dan harapan jika Kecap Bango dapat menembus pasar manca negara dengan adanya logo burung dan pegunungan di belakangnya.

\section{Kemasan}

Merupakan desain kreatif yang mengaitkan bentuk, struktur, material, warna, citra, tipografi dan elemen-elemen desain dengan informasi produk agar produk dapat dipasarkan. Kemasan digunakan untuk membungkus, mengeluarkan, menyimpan, mengidentifikasi dan membedakan sebuah produk di pasar (Klimchu, Marianne, \& Krasovec, 2006).

Pengemasan adalah aktivitas merancang dan memproduksi kemasan atau pembungkus untuk produk. Biasanya fungsi utama dari kemasan adalah 
untuk menjaga produk. Namun, sekarang kemasan menjadi faktor yang cukup penting sebagai alat peasaran (Rangkuti, 2010).

Jika dikaitkan dengan produk Bango, maka Bango memiliki kemasan yang beraneka ragam yang dapat disesuaikan dengan kebutuhan individu. Dengan warna dasar kemasan identik Bango yakni warna hijau, yang mana warna hijau memberikan makna sebuah ketenangan, kesegaran, dan pepohonan. Warna hijau banyak digunakan untuk kemasan produk yang berhubungan dengan pertanian, peternakan dan produk obat-obatan. Warna hijau dari kecap Bango ini merepresentasikan kedelai hitam malika yang merupakan suatu olahan pertanian dan juga kulit luar dari kedelai Malika. Kecap Bango terdiri dari kemasan botol gelas, botol plastik, kemasan isi ulang, dan sachet. Bango juga memiliki varian kecap manis pedas dengan kemasan warna hijau dan sedikit warna kuning untuk merepresentasikan cita rasa yang menggugah selera. Kemudian untuk varian kecap Bango Light kemasannya didesain dengan warna hijau tua di mana merupakan warna utama dari kecap Bango dengan sedikit hijau muda untuk merepresentasikan bahwa produk ini berbeda dari produk biasanya karena kadar gula yang ada pada vaian Bango Light ini lebih sedikit dibandingkan dengan varian lainnya.

\section{Supplier}

Bahan baku yang digunakan Kecap Bango adalah kacang kedelai hitam, gula kelapa, garam, dan air. Kacang kedelai hitam difermentasi selama beberapa bulan, sehingga akan menghasilkan rasa yang berbeda dibandingkan kecap yang dibuat dengan metode kimia atau kombinasi fermentasi dan kimia.

Gambar 3.

Mengelola Malika oleh Komunitas Perempuan

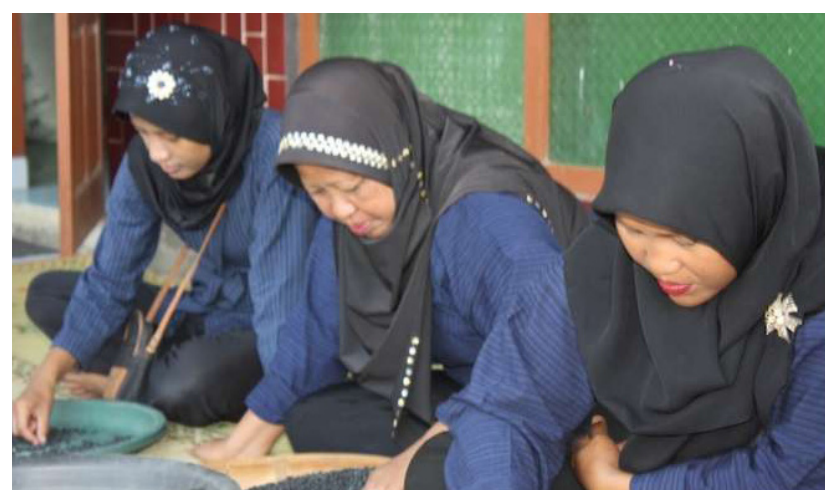

Sumber: Marketeers.com
Sejak awal tahun 2000-an, Unilever bekerjasama dengan Universitas Gadjah Mada menghasilkan kedelai hitam kualitas baik bernama "Malika". Kedelai tersebut menjadi kekuatan rasa dan merek Kecap Bango. Profesor Mary Astuti, penemu kedelai Mallika serta peneliti dan Guru Besar Fakultas Teknologi Pertanian, UGM, mengemukakan bahwa kedelai hitam Mallika memiliki banyak keunggulan dibandingkan varietas kedelai lainnya. Selain lebih tahan cekaman fisik dan serangan penyakit, kedelai hitam Mallika juga bernutrisi.

Memberikan modal kerja, bantuan penanaman, dan jaminan pasar tertentu atas hasil panen petani kedelai hitam. Kecap Bango membina lebih dari 9000 petani kedelai Malika dengan total persebaran lahan pertanian Malika semakin luas, dari 5 hektare pada tahun 2001 menjadi 1.600 hektare. Program tersebut membantu meningkatkan pendapatan serta kesejahteraan petani kedelai hitam Malika.

Melakukan kegiatan Festival Jajan Bango yang diikuti sejumlah penjaja makanan tradisional serta memberikan pembinaan di bidang penjualan. Acara tersebut juga memungkinkan penjaja makanan tradisional untuk memperkenalkan usaha mereka kepada masyarakat yang datang berkunjung. Memperkenalkan makanan tradisional melalui acara TV, Bango Cita Rasa Nusantara, sehingga dapat mengungkap berbagai makanan tradisional di seluruh Indonesia dan memberikan peragaan memasak.

Gambar 4.

Competitor

\begin{tabular}{|c|l|l|}
\hline No & \multicolumn{1}{|c|}{ Merek } & \multicolumn{1}{c|}{ Perusahaan } \\
\hline 1 & Kecap ABC & PT. Heinz ABC \\
\hline 2 & Kecap Bango & PT. Unilever \\
\hline 3 & Kecap Indofood & PT Indofood Sukses Makmur \\
\hline
\end{tabular}

Sumber: www.swa.co.id 
Gambar 5.

Harga Kecap

\begin{tabular}{|c|c|c|c|}
\hline No & Merek & Ukuran & Harga \\
\hline \multirow{8}{*}{1} & \multirow{8}{*}{ Kecap ABC } & Per sachet & 400 \\
\hline & & \begin{tabular}{|l|} 
Per 10 sachet \\
\end{tabular} & 4.000 \\
\hline & & $100 \mathrm{ml} /$ pouch & 2.000 \\
\hline & & $135 \mathrm{ml}$ botol & 7.500 \\
\hline & & $275 \mathrm{ml}$ botol & 13.500 \\
\hline & & $620 \mathrm{ml}$ botol & 17.800 \\
\hline & & Re fil $225 \mathrm{ml} /$ pouch & 8.400 \\
\hline & & Refil $520 \mathrm{ml} /$ pouch & 15.900 \\
\hline \multirow{8}{*}{2} & \multirow{8}{*}{ Kecap Bango } & $14 \mathrm{ml} /$ sachet & 500 \\
\hline & & Refil $100 \mathrm{ml} /$ pouch & 2.000 \\
\hline & & Refil $550 \mathrm{ml} /$ pouch & 23.300 \\
\hline & & $225 \mathrm{ml} /$ pouch & 2.500 \\
\hline & & $600 \mathrm{ml} /$ pouch & 13.500 \\
\hline & & $135 \mathrm{ml}$ botol & 8.500 \\
\hline & & $275 \mathrm{ml}$ botol & 19.000 \\
\hline & & $620 \mathrm{ml}$ botol & 21.000 \\
\hline \multirow{4}{*}{3} & \multirow{4}{*}{ Kecap Indofood } & $138 \mathrm{~m} 1 /$ botol & 5.103 \\
\hline & & $275 \mathrm{ml}$ botol & 10.716 \\
\hline & & Refil $200 \mathrm{ml} /$ pouch & 6.634 \\
\hline & & Refil $580 \mathrm{ml} /$ pouch & 17.861 \\
\hline
\end{tabular}

Sumber: Klik Indomaret

\section{Kecap ABC}

Kecap adalah salah satu bahan makanan yang jadi kesukaan banyak orang di segala usia. Untuk mempertahankan eksistensi dan citarasanya di tengah keluarga, Kecap manis ABC Mantap meluncurkan desain kemasan terbaru yang lebih modern dan dinamis.

Kecap $A B C$ dihadirkan dengan desain kemasan baru, tak ada perubahan komposisi dan rasa dalam kecap manis ini. PT. Heinz ABC sampai saat ini tetap mempertahankan citarasa kecap yang gurih dan nikmat sesuai dengan resep aslinya yang dibuat pada tahun 1975.

Salah satu bahan rahasia pembuatan Kecap $A B C$ adalah penggunaan kedelai kuning dan gandum. Dalam pembuatan kecap ini, gandum berperan untuk menambah rasa gurih dalam kecap, dan menambah kandungan protein.

Kecap manis $A B C$ sudah sejak lama berada di pasaran Indonesia sehingga masyarakat sudah tak asing lagi dengan produk kecap manis ini. Banyak tanggapan positif dengan produk kecap manis $A B C$ sehingga kecap $A B C$ mampu bersaing di pasaran dengan produk kecap manis yang baru. Berikut nilai evaluasi dan kepercayan responden terhadap kecap manis ABC.

Merek kecap manis ABC. Untuk atribut merek kecap manis $A B C$, konsumen sudah tidak asing lagi dengan nama merek kecap manis $A B C$ hal ini dikarenakan kecap manis $A B C$ yang sudah berdiri sejak lama sehingga konsumen hafal akan merek kecap manis $A B C$ dapat dilihat atribut merek.

Harga kecap manis $A B C$, untuk atribut harga kecap manis $A B C$, konsumen menilai bahwa kecap manis $A B C$ murah. Atribut harga kecap manis $A B C$ menjadi atribut yang sangat penting karena menjadi faktor utama dalam pembelian suatu produk kecap manis.

Volume kecap manis $A B C$, untuk atribut volume konsumen menilai cukup bervariasi karena kecap manis $A B C$ memiliki beragam variasi volume dari ukuran sachet hingga yang jerigen, terdapat 9 variasi volume yang ditawarkan oleh kecap manis $A B C$ yaitu sachet $13 \mathrm{ml}$, sachet $22 \mathrm{ml}$, refill $80 \mathrm{ml}$, 
refill $225 \mathrm{ml}$, refill $580 \mathrm{ml}$, botol $135 \mathrm{ml}$, botol 275 $\mathrm{ml}$, dan jerigen 5 liter.

Rasa kecap manis $A B C$, untuk atribut rasa kecap manis $A B C$ di nyatakan sangat enak oleh para konsumen, hal ini disebabkan karena kecap manis $A B C$ sudah muncul sejak lama sehingga konsumen yakin akan rasa kecap manis $A B C$ bahwa rasa pada kecap manis $A B C$ sangat enak.

Tanggal kadaluwarsa kecap manis $A B C$, untuk atribut tanggal kadaluwarsa pada kecap manis $A B C$ di nilai bahwa tanggal kadaluwarsa penting, karena atribut tersebut menentukan apakah kecap manis $A B C$ masih bisa dikonsumsi atau tidak.

Label halal kecap manis $A B C$, pada atribut label halal ini responden menilai penting karena responden pada kecap manis $A B C$ teliti akan produk yang sudah lama dikonsumsi sehingga responden sangat memperhatikan atribut label halal pada produk kecap manis ABC.

Iklan kecap manis $A B C$, atribut iklan pada kecap manis $A B C$ dinilai cukup menarik oleh konsumen di Desa Argodadi, hal ini dapat disebabkan iklan yang ditawarkan atau yang ditampilkan di media kurang maksimal sehingga konsumen menilai bahwa iklan kecap manis $A B C$ cukup menarik.

Ketersediaan kecap manis $A B C$, atribut ketersedian kecap manis $A B C$ dinilai baik karena faktor pemasaran kecap manis $A B C$ yang sudah merata di seluruh Indonesia. Kemasan kecap manis $A B C$, atribut kemasan kecap manis $A B C$ masih dinilai cukup menarik oleh konsumen di Desa Argodadi hal ini disebabkan banyak konsumen yang membeli kecap manis $A B C$ dalam kemasan sachet, dan pada kemasan sachet kecap manis $A B C$ dinilai kurang menarik.

Izin departemen kesehatan kecap manis $A B C$, atribut Izin departemen kesehatan dinilai cukup penting, hal ini disebabkan karena sebagian konsumen kurang memperhatikan atribut ini sehingga mereka menilai bahwa atribut ini dinilai cukup penting.

\section{Kecap Bango}

PT. Unilever mengubah tampilan merek, logo, dan kemasan Bango, yang dulunya dengan merek "Kecap Bango". Pada 1 Februari 2008, merek resmi diganti menjadi "Bango". Kemasannya beraroma lebih muda dengan warna-warna segar. PT.Unilever meremajakan Bango, namun rasa pada kecap Bango sangat dijaga kualitasnya sehingga masih banyaknya konsumen yang tertarik dengan kecap Bango.

Umur panjang pada kecap manis Bango juga ditunjang oleh distribusi dan penetrasi pasar yang kuat. PT.Unilever agresif memasarkan kecap manis Bango yang dahulunya kecap manis Bango hanya menguasai pasaran di daerah Jawa Barat dan Jakarta namun dengan jurus pemasaran yang agresif, sekarang kecap manis Bango sudah ada di semua kota di Indonesia. Kecap manis Bango juga diekspor ke negara di Asia Tenggara dan Arab Saudi. Kekuatan distribusi Unilever di dalam dan luar negeri menjadi kunci kuatnya penetrasi kecap manis Bango.

Kecap manis Bango juga menawarkan berbagai macam volume kecap, sehingga konsumen lebih mudah menyesuaikan kebutuhan yang diinginkannya, walaupun kecap manis Bango memiliki harga yang lebih tinggi dibanding kecap manis lainnya namun penelitian ini menunjukkan banyaknya konsumen yang mengkonsumsi kecap manis Bango dikarenakan kualitas rasa yang baik. Kecap manis Bango adalah kecap manis yang menjadi pesaing terberat dari kecap manis lainnya, pasalnya kecap manis yang berdiri pada tahun 2001 ini banyak diminati oleh konsumen. Namun dari hasil penelitian tidak semua atribut mendapatkan nilai kepercayaan yang sangat baik, berikut data nilai kepercayaan dan evaluasi kecap manis bango.

Merek kecap manis Bango. Untuk atribut merek kecap manis Bango, konsumen menilai bahwa merek kecap manis bango menarik hal ini dikarenakan konsumen percaya terhadap produk kecap manis Bango yang berdiri pada tahun 2001. Harga kecap manis Bango, untuk atribut harga kecap manis Bango, konsumen menilai bahwa kecap manis Bango termasuk murah, atribut harga kecap manis Bango menjadi atribut yang sangat penting karena menjadi faktor utama dalam pembelian suatu produk kecap manis.

Volume kecap manis Bango, untuk atribut volume konsumen menilai bervariasi karena kecap manis Bango memiliki beragam variasi volume dari ukuran sachet hingga yang jerigen, terdapat 8 variasi volume yang ditawarkan oleh kecap manis Bango yaitu sachet $14 \mathrm{ml}$ sachet $30 \mathrm{ml}$, refil $85 \mathrm{ml}$, refill $220 \mathrm{ml}$, refill $600 \mathrm{ml}$, botol $135 \mathrm{ml}$, botol 275 $\mathrm{ml}$, botol $620 \mathrm{ml}$ dan jerigen 5 liter.

Rasa kecap manis Bango, untuk atribut rasa kecap manis Bango dinyatakan sangat enak oleh para konsumen, hal ini desebabkan karena kecap manis Bango menjaga kualitas pada atribut rasa 
ANGELIA SAMPURNA, MONICA TANDIAN, VIVIANA HUANG, RUTH FLORESCIA SIMANJUNTAK, RUSTONO FARADY MARTA

sehingga konsumen yakin akan rasa kecap manis Bango sangat enak. Tanggal kadaluwarsa kecap manis Bango, untuk atribut tanggal kadaluwarsa pada kecap manis Bango konsumen di nilai bahwa tanggal kadaluwarsa cukup penting, karena sebagian konsumen kurang memperhatikan atribut ini, padahal atribut ini menentukan apakah kecap manis masih bisa dikonsumsi atau tidak.

Label halal kecap manis Bango, pada atribut label halal ini konsumen menilai cukup penting karena konsumen pada kecap manis Bango sebagian kurang memperhatikan atribut label halal sehingga atribut label halal pada kecap manis Bango dinilai cukup penting. Iklan kecap manis Bango, atribut iklan pada kecap manis Bango dinilai cukup menarik oleh konsumen, hal ini dapat disebabkan iklan yang ditawarkan atau yang ditampilkan dimedia kurang maksimal sehingga konsumen menilai bahwa iklan kecap manis Bango cukup menarik.

Ketersediaan kecap manis Bango, atribut ketersedian kecap manis Bango dinilai baik oleh konsumen hal ini disebabkan karena faktor pemasaran kecap manis Bango yang sudah mereata diseluruh Indonesia. Kemasan kecap manis Bango, atribut kecap manis Bango masih dinilai cukup menarik oleh konsumen hal ini disebabkan banyak konsumen yang membeli kecap manis Bango dengan kemasan isi ulang sehingga konsumen menilai kemasan isi ulang masih mudah tumpah apabila terjadi hal yang tidak diinginkan.

Izin Departemen Kesehatan kecap manis Bango, atribut lambang Izin departemen kesehatan dinilai cukup penting oleh konsumen, hal ini disebabkan karena sebagian konsumen kurang memperhatikan atribut ini sehingga responden menilai bahwa atribut ini dinilai cukup penting.

\section{Kecap Indofood}

PT. Indofood Sukses Makmur dan PT. Indofood CBP Sukses Makmur merupakan produsen berbagai jenis makanan dan minuman yang bermarkas di Jakarta, Indonesia. Perusahaan ini didirikan pada tanggal 14 Agustus 1990 oleh Sudono Salim dengan nama PT. Panganjaya Intikusuma yang pada tanggal 5 Februari 1994 menjadi Indofood Sukses Makmur. Perusahaan ini mengekspor bahan makanannya hingga Australia, Asia, dan Eropa.

Dalam beberapa dekade ini Indofood telah bertransformasi menjadi sebuah perusahaan total food solutions dengan kegiatan operasional yang mencakup seluruh tahapan proses produksi makanan, mulai dari produksi dan pengolahan bahan baku hingga menjadi produk akhir yang tersedia di rak para pedagang eceran.

Kecap manis Indofood masih kurang strategis dari hal pemasaran dan promosi dibandingkan kecap manis Bango dan kecap manis ABC. Promosi kecap manis Indofood masih sebatas media televisi saja, tidak seperti kecap manis pesaingnya yang mengadakan event atau acara masak bersama menyajikan sebuah masakan menggunakan brand kecap manis yang mereka produksi. Hal ini sangat berpengaruh terhadap keberlangsungan sebuah produk. Terlihat pada hasil penelitian ini masih sedikitnya konsumen yang mengkonsumsi kecap manis Indofood. Kecap manis Indofood adalah salah satu kecap manis yang menjadi pesaing kecap manis. Adapun respons konsumen terhadap kecap manis tersebut tidak seluruhnya baik terhadap atribut yang ada pada kecap manis Indofood berikut data nilai kepercayaan dari kecap Indofood.

Merek kecap manis Indofood. Sebagai atribut merek kecap manis Indofood, konsumen sudah tidak asing lagi dengan nama merek kecap manis Indofood. Harga kecap manis Indofood, untuk atribut harga kecap manis Indofood, konsumen menilai bahwa kecap manis Indofood murah, atribut harga kecap manis Indofood menjadi atribut yang sangat penting karna menjadi faktor utama dalam pembelian suatu produk kecap manis.

Volume kecap manis Indofood, untuk atribut volume konsumen menilai bervariasi karena kecap manis Indofood memiliki beragam variasi volume dari ukuran sachet hingga padaukuran yang terbesar, terdapat 6 variasi volume yang ditawarkan oleh kecap manis Indofood yaitu sachet $14 \mathrm{ml}$, refill $200 \mathrm{ml}$, refill $580 \mathrm{ml}$, refill $667 \mathrm{ml}$ botol $138 \mathrm{ml}$, dan botol $275 \mathrm{ml}$.

Rasa kecap manis Indofood, untuk atribut rasa kecap manis Indofood konsumen menilai enak, hal ini disebabkan karena kecap manis Indofood selalu menjaga kualitas rasa pada kecap manis sehingga konsumen dapat menilai bahwa rasa kecap manis Indofood enak.

Tanggal kadaluwarsa kecap manis Indofood, untuk atribut tanggal kadaluwarsa pada kecap manis Indofood konsumen menilai bahwa tanggal kadaluarsa penting, karena atribut tersebut menentukan apakah kecap manis Indofood masih bisa dikonsumsi atau tidak. 
Label halal kecap manis Indofood, pada atribut label halal ini konsumen menilai penting karena konsumen pada kecap manis Indofood teliti akan produk yang sudah lama dikonsumsi sehingga responden sangat memperhatikan atribut label halal pada produk kecap manis Indofood.

Iklan kecap manis Indofood, atribut iklan pada kecap manis Indofood dinilai cukup menarik oleh konsumen, hal ini dapat disebabkan iklan yang ditawarkan atau yang ditampilkan dimedia kurang maksimal sehingga konsumen menilai bahwa iklan kecap manis Indofood cukup menarik. Ketersediaan kecap manis Indofood, atribut ketersedian kecap manis Indofood dinilai baik hal ini disebabkan karena faktor pemasaran kecap manis Indofood yang sudah merata diseluruh Indonesia.

Kemasan kecap manis Indofood, atribut kecap manis Indofood masih dinilai cukup menarik oleh konsumen hal ini disebabkan banyak konsumen yang membeli kecap manis Indofood dalam kemasan sachet, dan pada kemasan sachet kecap manis Indofood tidak semenarik kemasan dari kecap manis pesaing.

Izin departemen kesehatan kecap manis Indofood, atribut lambang Izin departemen kesehatan dinilai penting oleh konsumen, hal ini disebabkan karena konsumen teliti memperhatikan atribut ini sehingga konsumen menilai bahwa atribut ini dinilai penting.

\section{Distributor}

Pada tahun 1992, PT. Unilever Indonesia tertarik untuk mengakuisisi merek dan usaha Kecap Bango di bawah naungan perusahaan mereka. Akhirnya Kecap Bango resmi menjadi salah satu produk PT. Unilever Indonesia pada tahun 2001. Setelah proses akuisisi, nama dan performa Kecap Bango semakin kencang dan dikenal hingga luar Jakarta. Langkah awal setelah akuisisi, Unilever mengubah tampilan merek, logo, dan kemasan Bango. Dulu mereknya "Kecap Bango". Pada 1 Februari 2008, mereknya resmi menjadi "Bango".

Unilever dan keluarga Kartadinata membentuk perusahaan patungan bernama PT Anugrah Lever. Perusahaan ini memproduksi dan memasarkan kecap, sambal, dan saus bermerek Bango. Unilever menguasai 65 persen saham, sisanya 35 persen dimiliki Anugrah Indah Pelangi dan Anugrah Damai Pratama. Pada 2007, Unilever mengakuisisi sisa saham Bango milik keluarga Kartadinata (Herawati \& Ekawati, 2016).
Unilever merupakan produsen barang rumah tangga terbesar ketiga di dunia, jika didasarkan pada besarnya pendapatan pada tahun 2012, di belakang P\&G dan Nestlé. Unilever memasok produknya mulai dari pasar swalayan hingga tradisional seperti Indomaret, Alfamart, Transmart, dan sebagainya.

\section{SIMPULAN}

Kesimpulan dalam penelitian ini bahwa Kecap Bango dalam implementasi total branding secara umum telah memenuhi seluruh aspeknya, baik dalam pemasaran, menjaga dengan baik citra yang sudah dibentuk dari awal yang dimulai dari kontributor, supplier, distributor, kompetitor hingga pelanggan. Pelaksanaan seluruh aspek IMC tersebut sudah cukup aktif pada implementasi Kecap Bango.

Sehingga Kecap Bango, sadar atau tidak sadar memiliki pedoman dasar dalam memilih dan melakukan aktivitas Intergrated Marketing Communication atau IMC. Kompleksitas aspek segmentation, targeting, dan positioning menjadi pertimbangan tersendiri dalam perencanaan dan penerapan implementasi total branding dalam komunikasi pemasaran terpadu yang dilakukannya.

Kecap Bango dalam melakukan pemasaran salah satu contohnya yang cukup fenomenal adalah festival jajanan bango pada tahun 2008 yang bertujuan untuk melestarikan makanan tradisional Indonesia. Kemudian juga, untuk mengatasi customer loyalty yang relatif menurun perusahaan Unilever juga melakukan diferensiasi pada produk kecap Bango untuk mempertahankan dan meningkatkan loyalitas pelanggan. Hal ini, karena mereka memiliki marketing plan uang dibuat secara matang dan menyentuh seluruh aspek pemasaran. Penyusunan strategi yang sama dilakukan dengan baik melalui aspek-aspek packaging yang dilakukan mulai dari distributor hingga kontributor.

\section{DAFTAR PUSTAKA}

Aaker, D. (2008). Managing Brand Equity. New York: Free Press.

Azzahrani, M. (2018). Strategi Komunikasi Pemasaran Kementerian Pariwisata Indonesia dalam Pesona Indonesia melalui Youtube. Manajemen Komunikasi, 2(2), 144-161.

Belch, B. (2009). Advertising \& Promotion: An Integrated Marketing Communication Perspective. New York: McGraw Hill. 
ANGELIA SAMPURNA, MONICA TANDIAN, VIVIANA HUANG, RUTH FLORESCIA SIMANJUNTAK, RUSTONO FARADY MARTA

Delgado-Ballester, E., \& Munuera-Alemán, J. L. (2005). Does Brand Trust Matter To Brand Equity? Journal of Product and Brand Management, 14(3), 187-196. https://doi. org/10.1108/10610420510601058

Fajrin, F. V., \& Wibowo, S. (2018). Pengaruh Event Marketing Terhadap Brand Image Pada Pt Pikiran Rakyat Bandung Tahun 2018. Jurnal Manajemen Pemasaran. https://doi. org/.1037//0033-2909.126.1.78

Farady, R., \& Septyana, V. (2015). Semiotika Pemasaran Pada Brand Value Melalui Sign Berupa Layout Berita dan Iklan Ibadah Haji ( Studi Komparasi pada Harian Pos Kota dengan Rakyat Merdeka ). Semiotika, 9(2), 482-508.

Fensi, F., \& Christian, M. (2018). Determinan Citra Merek Pada Iklan Produk Gawai "VIVO" Berdasarkan Aspek "Celebrity Endorser." Bricolage: Jurnal Magister Ilmu Komunikasi, 4(2), 163-179.

Hardhiyanti, Y. (2017). Komunikasi Bisnis Berbasis Etika Lingkungan Sebagai CSR The Body Shop Indonesia ( Studi Kasus: Kampanye \# Pay4Plastic ). Bricolage : Jurnal Magister IImu Komunikasi, 3(2), 103-117.

Haryono, D. (2015). Pengaruh Relationship Marketing Terhadap Loyalitas konsumen dengan Kepuasan Konsumen dan Komitmen Konsumen sebagai Variabel Antara. Jurnal Ekonomi Universitas Muhammadiyah Yogyakarta, 1-16.

Herawati, H., \& Ekawati, D. (2016). Pengaruh Perencanaan Pajak Terhadap Nilai Perusahaan. Jurnal Riset Akuntansi Dan Keuangan. https:// doi.org/10.17509/jrak.v4i1.7708.

Ishak, A. (2012). Peran Public Relations dalam Komunikasi Organisasi. Jurnal ASPIKOM, 1(4), 373. https://doi.org/10.24329/aspikom. v1i4.38

Jefkins, F. (1997). Periklanan. (Penerjemah: Haris Munandar). Jakarta: Erlangga.

Johannes, D. T. W. (2017). Komunikasi Bisnis Pada Etnis Tionghoa Studi Kasus di Warung Kopi Asiang, Kota Pontianak, Kalimantan Barat. Bricolage: Jurnal Magister Ilmu Komunikasi, 3(2), 118-155. Retrieved from https://journal. ubm.ac.id/index.php/bricolage/issue/view/150

Kertajaya, Hermawan, Yuswohadi, Musri, J., \& Taufik. (2004). Positioning, Differensiasn, and Brand. Jakarta: PT. Gramedia Pustaka Utama.
Klimchu, Marianne, \& Krasovec, A. S. (2006). Desain Kemasan. Jakarta: Erlangga.

Konsep Marketing Public Relation (MPR): Definisi dan Peran Marketing Public Relation. (2009). Jurnal Manajemen.

Kotler, \& Keller. (2007). Manajemen Pemasaran. Jakarta: PT. Indeks.

Kotler, \& Philip \& Pfoetsch W. (2006). Ingredient Branding - Making the Invisible Visible. London: Springer Heidelberg Dordrecht.

Kriyanto, R. (2008). Teknik Praktis Riset Komunikasi: Disertai Contoh Praktis Riset Media, Public Relations, Advertising, Komunikasi Organisasi, Komunikasi Pemasaran. Jakarta: Kencana.

Lestari, S. P. (2015). Hubungan Komunikasi Pemasaran dan Promosi Dengan Keputusan Memilih Jasa Layanan Kesehatan (Studi Pada Rumah Sakit Islam Lumajang). Interaksi: Jurnal IImu Komunikasi, 4(2), 139-147. https://doi. org/10.14710/Interaksi.4.2.139-147

Lubis, F. W. (2008). Peranan Komunikasi Dalam Organisasi. Jurnal Harmoni Sosial.

Marta, R. F. (2015). Analisis Wacana Kritis Film "Puteri Giok": Cermin Asimilasi Paksa Era Orde Baru. Masyarakat Dan Budaya, 17(1), 331-346. https://doi.org/10.14203/jmb.v17i3.323

Marta, R. F., Fernando, J., \& Simanjuntak, R. F. (2019). Eksplikasi Kualitas Konten Peran Keluarga Pada Instagram @Kemenpppa.Ettisal, 4(2), 137-149.

Marta, R. F., \& William, D. M. (2016). Studi Terpaan Media Pemasaran Melalui Posting Instagram Terhadap Ekuitas Merek Pelanggan Sumoboo! (Analisis Eksplanatif pada Komunitas Food Blogger \#WTFoodies). Jurnal Komunikasi, 8(1), 68-82. Retrieved from https://journal.untar. ac.id/index.php/komunikasi/article/view/50

McAlexander, J. H., Schouten, J. W., \& Koenig, H. F. (2002). Building brand community. Journal of Marketing. https://doi.org/10.1509/ jmkg.66.1.38.18451

Meutia, Y. R. (2016). Standardisasi Produk Kecap Kedelai Manis Sebagai Produk Khas Indonesia. Jurnal Standardisasi, 17(2), 147. https://doi. org/10.31153/js.v17i2.314

Mulyadi, D. W., \& Mulia, U. B. (2020). Logika Orkestrasi Pada Rangkaian Komunikasi Pemasaran Logic of Orcestration on Integrated Marketing Communication Concatenation 
Through Lifebuoy 's Healthy Sharing. III(I), 120-138.

Oswald, L. (2012). Marketing Semiotics: Signs, Strategies, and Brand Value. United States: Oxford University Press.

Puspitasari, L., Mahameruaji, J. N., \& Indriani, S. S. (2017). Publisitas dan Promosi Film Ada Apa Dengan Cinta? 2. ProTVF, 1(2), 169-176.

Rangkuti, F. (2010). Analisis SWOT Teknik Membedah Kasus Bisnis. Jakarta: PT. Gramedia Utama.

Rezki, M. A., \& Hapsari, D. R. (2019). Efektivitas Strategi Promosi Produk Kopi Lokal di Rumah Kopi Ranin. Jurnal Komunikasi Pembangunan, 17(1), 38-54.

Rosyadi, M. I. (2018). Analisis Strategi Marketing Public Relations PT. Bank Rakyat Indonesia (Persero) tbk dalam Meningkatkan Pengguna Kartu Brizzi. Jurnal Komunikator, 10(1), 1-9.

Sari, T. W., \& Semiarty, R. (2019). Integrated Marketing Communication (IMC) Program Design At Naili Dbs Hospital. Jurnal Procuratio, 7(4), 484-495.

Southgate, P. (1995). Total branding. Journal of Brand Management, 2(5), 280-288. https://doi. org/10.1057/bm.1995.11

Sularko, H., Prawata, V., \& M, W. (2008). How Do They Think. Jakarta: Mosher.

Sunardi. (2004). Semiotika Negative. Yogyakarta: Buku Baik.

Tarsani. (2016). Strategi Komunikasi Pemasaran Dompet Dhuafa dalam Meningkatkan Kepercayaan Muzakki. Bricolage, 2(1), 56-70. Retrieved from https://journal.ubm.ac.id/ index.php/bricolage/article/view/834

Tinarbuko, S. (2008). Semiotika Komunikasi Visual. Yogyakarta: Jalasutra.

Tumpal, J., \& Hasugian, M. (2015). Pengaruh Brand Image dan Brand Trust Terhadap Brand Loyalty Telkomsel (Survey Terhadap Pelanggan Telkomsel di Grapari Samarinda). EJournal IImu Administrasi Bisnis, 3(4), 923-937.

Ulfa, R., \& Marta, R. F. (2016). Implementasi Komunikasi Pemasaran Terpadu Pada Yayasan Nurul Ibad Jakarta Timur. Bricolage: Jurnal Magister Ilmu Komunikasi, 2(2), 71-81.

Venessa, I., \& Arifin, Z. (2017). Pengaruh Citra Merek (Brand image) dan Harga Terhadap Keputusan Pembelian Konsumen (Survei pada Mahasiswa 